\title{
Perception and demand for artificial reef by relevant local groups in Altınoluk (Turkey)
}

\author{
Altınoluk'ta ilgili grupların yapay resif algısı ve talebi \\ Sezgin Tunca*1 • Bülent Miran² • Vahdet Ünal ${ }^{3}$ \\ 1Department of Marine Sciences and Applied Biology, University of Alicante, 03080, Alicante, Spain \\ ${ }^{2}$ Ege University, Faculty of Agriculture, Department of Agricultural Economics, 35100, Bornova, Izmir, Turkey \\ ${ }^{3}$ Ege University, Faculty of Fisheries, Department of Fishery and Fish Processing Technology, 35100, Bornova, Izmir, Turkey \\ *Corresponding author: sezgin.tunca@gmail.com
}

How to cite this paper:

Tunca, S., Miran, B., Ünal, V., 2014. Perception and demand for artificial reef by relevant local groups in Altınoluk (Turkey). Ege J Fish Aqua Sci 31(1): 5-10.

doi: 10.12714/egejfas.2014.31.1.02

Özet: Bu çalışmada, Türkiye Ulusal Yapay Resif Master Planı'nın pilot bölgesi olan Altınoluk'da yerleştirimesi planlanan yapay resiflere olan talebin belirlenmesi amaçlanmaktadır. Çalışma kapsamında, Altınoluk'daki ticari balıkçılar, rekreasyonel balıkçılar ve yöre sakinleri ile yüz yüze görüşmeler gerçekleştirilmiştir. Veri toplama çalışmaları, yapay resif yerleştirmesi yapılmadan önce, Nisan, 2011'de tamamlanmışıı. Çalışma hedef gruplarının yapay resif algısı özel olarak tasarlanan 13 ifade Likert ölçeği yardımılla analiz edilmiştir. Elde edilen sonuçlara göre, yapay resifler ile ilgili olumlu algı gözlenmiştir. Öte yandan, yapay resif yerleştirilmesi ile birlikte hem rekreasyonel balıkçılık (\%158 artış) hem de ticari balıkçılık (31\% artıs) günlerinde artış tespit edilmiştir. Sonuç olarak, yapay resiflerle ilişkili grupların daha iyi anlaşıması ve yönetim süreçlerine dahil edilmesi yapay resiflerin etkinliği açısından önem taşımaktadır.

Anahtar kelimeler: Yapay resifler, algı, rekreasyonel ve ticari talep, yönetim.

Abstract: In this study, it is aimed to determine demand for the planned artificial reefs in Altinoluk where is the pilot site of the National Artificial Reefs Master Planof Turkey. Face to face interviews were conducted with commercial fishermen, recreational fishermen and local residents within the study. Data collection process was completed in April, 2011 before the artificial reefs deployment was launched. Artificial reef perception of the study target groups were analyzed by specially designed 13 statements with the aid of Likert scale. According to the results, positive perception regarding the artificial reefs was observed. Moreover, increases in both recreational fishing (158\% increase) and commercial fishing (31\% increase) days was determined with the deployment of artificial reefs. In conclusion, understanding artificial reef related groups and including them in management processes are crucial for the effectiveness of artificial reefs.

Keywords: Artificial reefs, perception, recreational and commercial demand, management

\section{INTRODUCTION}

Artificial habitats, deployed on the seafloor to conserve sensitive aquatic ecosystems or increase and contribute to the productivity of resources, have positive effects on commercial and recreational fishing (Seaman and Sprague, 1991). Artificial Reef (AR) deployments have recently become popular in Turkey where the first planned AR application dates back 20 years. Within the Master Plan of Turkish Artificial Reefs, a pilot project in Altınoluk (Edremit Bay) has been started to contribute to the marine life.

Deployments of ARs have many purposes including support to small-scale and traditional fisheries, to create new sites for recreational fishing and diving, to protect biodiversity, especially in the littoral zone, to protect fish-spawning and nursery areas from illegal trawling (Lök, 2012). Therefore, directly or indirectly, ARs constitute commercial and recreational demand which means an increased economic activity in the area where they were deployed. Hence, deployment of ARs contributes to increase welfare locally and nationally (Ditton et al., 2002; Morgana et al., 2009; Oh et al., 2008; Pendleton, 2004; Tunca, 2011; Tunca et al., 2012).

Schug (1982) estimated total yearly expenditure of ARs users as 181,000-253,000 USD whereas, benefit - cost ratio of ARs was determined as over one. Study by Brock (1994) indicated both considerable positive effects of ARs: (1) Total yearly income by commercial (small scale) fishing was equal to $4 \%$ of one day diving charter to ARs, (2) Daily catch from ARs site was equal to yearly sustainable catch which means that the almost total catch was from the ARs site. The most comprehensive study was carried out by Bell et al. (1998) in the Northwest Florida.They demonstrated that there are 414 million USD contribution of ARs beside 8,136 new job opportunities and 84 million USD increase in salaries. In the Southwest Florida, ARs created 27,000 employments, beside 782 million USD increase in all incomes (Johns et al., 2001). 
ARs have been well-introduced as economy generator tools but the structure of multi-stakeholder (Commercial and recreational fishermen and SCUBA divers, etc.) (Milon, 1989a; 1989b) of ARs may cause conflicts because of the lack of management practices combined with Integrated Coastal Zone Management frameworks. Recent acts on management of ARs have already been begun to discuss (GFCM, 2012). In the management plans it is crucial to include constant social and economic monitoring of ARs.

This study primarily aims to measure the perception toward to ARs with specifically designed 13 statements covering biological, social and economic aspects. Secondly, it was aimed to calculate current and future estimated commercial and recreational demand of ARs. Finally it was aimed to provide information for decision makers about the demand framework of ARs.

\section{Study site}

The research was carried out in Altınoluk which is fishing and tourism district with the 13,800 population located innorthern Aegean coast of Turkey (Figure 1). Altınoluk County was found eligible for thepilot project of Turkish National AR Master Plan. Small-scale fishery dominates fishing activity in Altınoluk. 95\% (55 commercial fishermen) of fishermen are organized under the Altınoluk Fishery Cooperative in the region. Altınoluk Fishery Cooperative was established in 2006 with the support and leadership of an extraordinary and innovator local fisher. The cooperative keeps seven employees permanently during the whole year and twenty employees temporarily during the summer time due to it also runs cafe, restaurant and aquarium (Ünal et al., 2009). In this region, recreational fishing is another demanding activity on shore and/or by boat, and nearly 400 recreational fishermen attending this activity. Additionally, there is one diving charter in Altınoluk which only activates in the summer season.

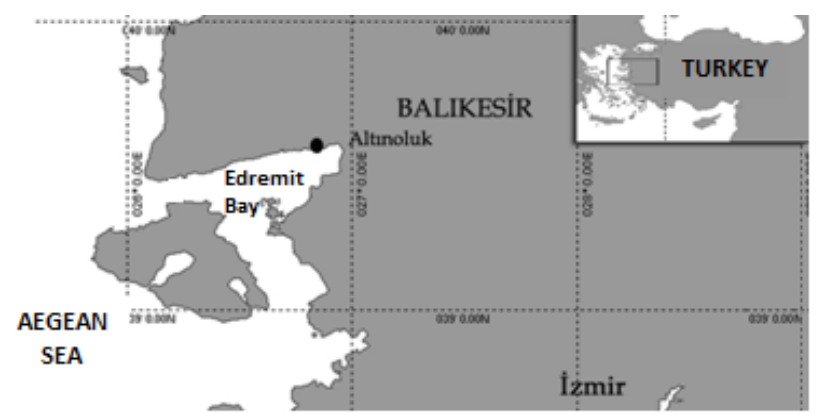

Figure 1. Map of Turkish Aegean Sea coasts with the study area: Altınoluk

\section{MATERIALS AND METHOD}

Field studies were conducted to collect data from target survey groups via specifically designed questionnaire forms. Twenty commercial fishermen (CF) who are members of the Altınoluk Fishery Cooperative responded the questionnaires. Out of approximately four hundred recreational fishermen (RF) in the region, fifty five boat-based and shore-based RF were interviewed in fishing access points around Altınoluk fishing port. Lastly, for 13,800 local residents (LR) of Altınoluk, household survey was conducted through $67 \mathrm{LR}$. The sampling sizes for each group were determined by using the proportional sampling size formula in Equation 1.

$$
n={\frac{N p(1-p)}{(N-1){\sigma_{\mathrm{px}}}^{2}+p(1-p)}}_{(\text {Equation 1) }}
$$

Where $n$ is the sample size, $N$ is the population of each target group (CF, RF and LR), $p$ is the contribution ratio to ARs ( 0.50 is used to reach the maximum sample size), and $\sigma_{p x^{2}}$ is the variance. Representative sample size was calculated for each group according to $95 \%$ confidence interval and 50\% error (Miran, 2003).

Additionally, basic descriptive statistics and parametric tests (analysis of variance, Kolmogorov-Smirnov and Tukey's Post Hoc Test) were used to better understand relations between socioeconomic dimensions and AR demand.

\section{RESULTS}

\section{Demographics}

A total of $55 \%$ of the CF were in the $26-45$ age group, while $40 \%$ of them were in the $46-60$ age group. Among the recreational fishers interviewed, members of the 26-45 age group composed the highest portion and secondly, the 46-60 age group, as in the case of the commercial fishers. Furthermore, it was determined that 6 RF were older than 61 years and 1 recreational fisherman were younger than 26 years. Among the household respondents who participated in the research, the $26-45$ and $46-60$ age groups had $53.7 \%$ and $31.3 \%$ of the respondents, respectively, whereas respondents were older than 61 years and younger than 26 years constituted minorities. The most common education levels of the CF were about eight years of secondary education. In contrast, RF have higher educational levels, with an average of 9.3 years. The mean period of education of the local people was 10.8 which are slightly higher than the general average for all of the respondents' education levels (9.9). The RF had the highest proportion of members with social security (89.7\%). Following them, $80.6 \%$ of the local people and $60 \%$ of the CF had social security. A total of $34.5 \%$ of the RF were retired persons. Following those people, public servants and freely occupied individuals constituted the majority of this group. Among all of the respondents, retired persons composed the majority, with 40 individuals, while freely occupied persons, public servants, workers for a national company and fishermen almost homogeneously composed the majority of the rest of the individuals (105). The average monthly income of the CF was 1192.5 TL (1 TL: Turkish Liras=0.37 Euro, Spring-2011 TL/Euro Mean Ratio), while 
$75 \%$ of them were in the $501-1500 \mathrm{TL}$ income group and $25 \%$ of them were in the 1501-3000 TL income group. $79 \%$ of the $\mathrm{RF}$, were in the 501-1500 TL income group, although the mean monthly income was determined to be $1354.1 \mathrm{TL}$ greater thanthe commercial fishers' monthly mean income. In contrast, the local people's monthly income was mostly in the 1501-3000 TL income group (mean $1360.5 \mathrm{TL}$ ). Moreover, for the local people, $30 \%$ had an income of 3001-5000 TL, and $15 \%$ was in the 5001-10000 TL income group. Overall, the $1501-3000 \mathrm{TL}(66 \%)$ and $3001-5000 \mathrm{TL}(24 \%)$ income group composed the majority. Additionally, the mean number of individuals that the $\mathrm{CF}$ were responsible for was nearly two and that of the average household population was three. These numbers were different for the RF, who were on average responsible for only one individual, and the total family population was three, as in the case of the CF. The local people were on average responsible for two individuals, and the mean household number was three. Generally, the mean number of individuals that all of the respondents were responsible for was approximately two, and the mean household population was about three.

To deeply investigate the relations among demand and socioeconomic variables, statistical tests were done. Firstly, normal distribution was determined by Kolmogorov-Smirnov Test for each commercial and recreational demand data sets of $C F, R F$ and $L R$ including the number of yearly current commercial or recreational fishing/diving/trip days in ARs site $(p>0.05)$; the number of yearly current commercial recreational fishing/diving/trip fishing days $(\mathrm{p}>0.05)$ and future stated commercial fishing days in ARs site after the deployment $(\mathrm{p}>0.05)$.

Then, in the study, the possible effect of education (education levels in years: below 5; 5-8; 8-11; above 11) and income (Income levels: below $1000 \mathrm{TL} ; 1000-3000 \mathrm{TL}$; above $3000 \mathrm{TL}$ ) on commercial/recreational demand was analyzed for each group via analysis of variance (ANOVA) with an additional Tukey's Post-Hoc Test.The number of commercial fishing days each year in the ARs site $(p>0.05)$, the number of total yearly commercial fishing days $(p>0.05)$ and future stated commercial fishing days in the ARs site after deployment $(p>0.05)$ was found not to have statistically significant relation with education level. The ANOVA analysis was also performed for the RF and the LR to present the effect of education level on demand (Present recreational fishing days in ARs site ( $p>0.05)$, total yearly recreational fishing days $(p>0.05)$, future recreational fishing days in ARs site after deployment $(p>0.05)$, but no statistically significant relation was found. For the $L R$, education and income has also no statistically significant effect on recreational trips done ( $p>0.05)$. Above found results proves the fact that education level and income levels have no effect on commercial and recreational demand of study groups.

\begin{tabular}{|c|c|c|c|c|c|}
\hline & & & $\begin{array}{c}\text { Current CF/RF } \\
\text { Days }^{1}\end{array}$ & $\begin{array}{c}\text { Total Yearly } \\
\text { Days }^{2}\end{array}$ & Future CF/RF Days $^{3}$ \\
\hline \multirow{8}{*}{ 峲 } & & Below 5 years $(\mathrm{N}=6)$ & $118 \pm 82.8$ & $205 \pm 50.5$ & $103 \pm 98.3$ \\
\hline & 흐 & $5-8$ years $(\mathrm{N}=7)$ & $150 \pm 70.7$ & $260 \pm 34.6$ & $179 \pm 110.4$ \\
\hline & 芯 & 8-11 years $(\mathrm{N}=5)$ & $86 \pm 68.8$ & $230 \pm 57$ & $170 \pm 97.5$ \\
\hline & 宽 & Above 11 years $(\mathrm{N}=2)$ & $50 \pm 70.7$ & $250 \pm 70.7$ & $150 \pm 70.7$ \\
\hline & & Total $\mathrm{N}=20$ & $115 \pm 75.9$ & $235 \pm 50.4$ & $151 \pm 98.7$ \\
\hline & & Below $1000 \mathrm{TL}(\mathrm{N}=13)$ & $128 \pm 72.9$ & $235 \pm 40.5$ & $126 \pm 97.9$ \\
\hline & 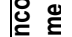 & $1000-3000 \mathrm{TL}(\mathrm{N}=7)$ & $90 \pm 80.8$ & $236 \pm 7$ & $197 \pm 88.8$ \\
\hline & & Total $(\mathrm{N}=20)$ & $115 \pm 75.9$ & $235 \pm 50.5$ & $151 \pm 98.7$ \\
\hline \multirow{9}{*}{ 㭊 } & & Below 5 years $(\mathrm{N}=14)$ & $42 \pm 60.3$ & $128 \pm 80.4$ & $102 \pm 72.9$ \\
\hline & б & $5-8$ years $(\mathrm{N}=13)$ & $26 \pm 39.3$ & $117 \pm 59.9$ & $84 \pm 78.6$ \\
\hline & 营 & $8-11$ years $(N=19)$ & $46 \pm 47.9$ & $134 \pm 91.1$ & $69 \pm 47.6$ \\
\hline & $\frac{\mathrm{g}}{0}$ & Above 11 years $(\mathrm{N}=12)$ & $37 \pm 42.9$ & $113 \pm 68.9$ & $110 \pm 74.7$ \\
\hline & & Total $(\mathrm{N}=58)$ & $39 \pm 47.9$ & $124 \pm 76.4$ & $89 \pm 67.7$ \\
\hline & & Below $1000 \mathrm{TL}(\mathrm{N}=30)$ & $35 \pm 36.2$ & $133 \pm 70.9$ & $99 \pm 66.6$ \\
\hline & $\stackrel{\Xi}{\Xi}$ & $1000-3000$ TL $(\mathrm{N}=26)$ & $46 \pm 59.3$ & $118 \pm 82.3$ & $79 \pm 68.7$ \\
\hline & ờ & Above $3000 \mathrm{TL}(\mathrm{N}=2)$ & 0 & $63 \pm 81.3$ & $65 \pm 91.9$ \\
\hline & & Total $(\mathrm{N}=58)$ & $39 \pm 47.9$ & $124 \pm 76.4$ & $89 \pm 67.7$ \\
\hline \multirow{9}{*}{$\stackrel{\exists}{\simeq}$} & & Below 5 years $(\mathrm{N}=6)$ & $23 \pm 38.3$ & $38 \pm 57.8$ & $8 \pm 11.6$ \\
\hline & 흐 & $5-8$ years $(\mathrm{N}=19)$ & $34 \pm 68.5$ & $50 \pm 75.7$ & $30 \pm 14.5$ \\
\hline & 葋 & $8-11$ years $(N=22)$ & $37 \pm 55.2$ & $52 \pm 65.1$ & $15 \pm 19.5$ \\
\hline & $\frac{3}{3}$ & Above 11 years $(\mathrm{N}=20)$ & $59 \pm 82.9$ & $85 \pm 95.8$ & $14 \pm 16.4$ \\
\hline & & Total $(\mathrm{N}=67)$ & $41 \pm 67$ & $60 \pm 78$ & $18 \pm 22.7$ \\
\hline & & Below $1000 \mathrm{TL}(\mathrm{N}=32)$ & $35 \pm 58.5$ & $54 \pm 67.9$ & $22 \pm 27.6$ \\
\hline & $\stackrel{\dddot{\Xi}}{E}$ & $1000-3000 \mathrm{TL}(\mathrm{N}=32)$ & $45 \pm 72.1$ & $64 \pm 86.7$ & $13 \pm 14.3$ \\
\hline & ¿্ট & Above $3000 \mathrm{TL}(\mathrm{N}=3)$ & $110 \pm 127.3$ & $120 \pm 113.1$ & $23 \pm 31.8$ \\
\hline & & Total $(\mathrm{N}=67)$ & $41 \pm 67$ & $60 \pm 78$ & $18 \pm 13.6$ \\
\hline
\end{tabular}

${ }^{3}$ Future commercial/recreational fishing days onthe ARs site after deployment N: Number of Observations, SD: Standart Deviation 
Table 2.Perception assessment through statements

\begin{tabular}{|c|c|c|c|c|}
\hline Statements & CF & RF & LR & General \\
\hline ARs increase biodiversity and quantity of living beings. & 5 & 5 & 4.3 & 4.6 \\
\hline ARs increase the number of commercial and recreational fishing vessels. & 4.5 & 4.5 & 3.6 & 4 \\
\hline ARs increase the number of commercial and RF. & 4.4 & 4.4 & 4.1 & 4.2 \\
\hline ARs increase the number of diving clubs and their activities. & 4.7 & 4.7 & 4.3 & 4.5 \\
\hline ARs protect some marine living species. & 4.6 & 4.6 & 4.3 & 4.4 \\
\hline $\begin{array}{l}\text { ARs help to put away conflicts rising among stakeholders related to use of } \\
\text { marine zone. }\end{array}$ & 2.5 & 2.5 & 3.4 & 3.4 \\
\hline ARs decrease pressure on natural reefs. & 4 & 4 & 3.5 & 3.8 \\
\hline ARs play an important role on combating illegal fishing. & 3.6 & 4.3 & 3.8 & 3.7 \\
\hline $\begin{array}{l}\text { Constant control of ARs must be provided by a reef guard station and } \\
\text { employees. }\end{array}$ & 4.3 & 4.6 & 4.7 & 4.6 \\
\hline $\begin{array}{l}\text { Constant control of ARs must be provided by fishery cooperatives, diving } \\
\text { organizations or municipalities. }\end{array}$ & 4.6 & 3.8 & 4.2 & 4.2 \\
\hline ARs increase fishing pressure on the marine zone where it has practiced. & 3.8 & 2.9 & 3.9 & 4 \\
\hline ARs cause more fishing gear damage. & 2.9 & 3.1 & 3.2 & 3.1 \\
\hline ARs cause conflicts among divers, commercial and RF concerning their use. & 3.1 & 5 & 3 & 3.3 \\
\hline
\end{tabular}

The statement "ARs help to resolve conflicts rising among stakeholders related to use of marine zones" received significantly lower agreement from the three groups, while the respondents strongly agreed with the statements "ARs decrease pressure on natural reefs" and "ARs play an important role in combating illegal fishing". By comparing the responses to two statements "Constant control of ARs must be provided by a reef-guard station and employees" and "Constant control of ARs must be provided by fishery cooperatives, diving organizations or municipalities", it is thought that a functional reef-guard station can be an acceptable and objective management and control tools for ARs.

Particularly, RF had slightly low agreement with management and control except for a reef-guard station of ministry. The statement "ARs increase fishing pressure in the marine zone where the $A R$ is placed" was well accepted by the $\mathrm{CF}$ and $\mathrm{LR}$, but RF only moderately agreed with this statement. Moderate agreement by all three of the groups was found for the statement "ARs cause more fishing-gear damage". Finally, the statement "ARs cause conflicts among divers, commercial and RF concerning their use" received moderate agreement from the CF and LR, and the RF strongly agreed with that statement (Table 2).

\section{AR Demand in the site: Use Types of AR Site}

\section{Commercial Fishing Use}

Technical and economic dimensions of CF were assessed in this section. $95 \%$ of the $\mathrm{CF}$ indicated that they are active in terms of fishing in and/or around the predetermined pilot ARs site. In addition, $40 \%$ of the $\mathrm{CF}$ is attending 50 and below 50 commercial fishing days whereas, $35 \%$ of the CF stated that they are attending 101-200 commercial fishing days in a year. Then, half of the CF indicated that they are participating 201-
365 fishing days in ARs region and the other half is participating 101-200 days in a year (Figure 2).

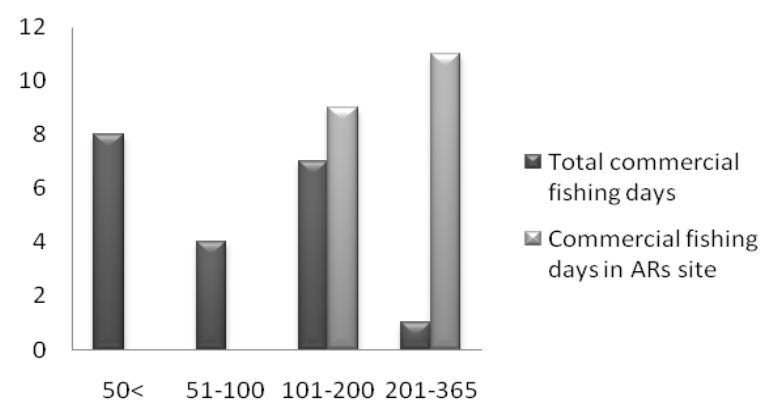

Figure 2.Total commercial fishing days and commercial fishing days in the ARs site.

Total yearly average commercial fishing days were determined as 235 whereas, present and future commercial fishing days in the ARs site were orderly determined as 115 and 151 (Table 3; Figure 3). With the attribution of present and future stated commercial fishing days to the total $55 \mathrm{CF}$ who are member of the Altınoluk Fishery Cooperative, total yearly present and future demand were calculated as 6,325 and 8,305 commercial fishing days, respectively. Except small scale fishermen in Altınoluk, surrounding local fishermen and cooperatives constitute another potential commercial demand in the region.

Table 3. Descriptive statistics of total yearly commercialfishing days and commercial fishing days in the ARs site

\begin{tabular}{r|c|c|c|c}
\hline & Mean & Min & Max & SD \\
\hline Current CF days $^{1}$ & 115 & 0 & 250 & 75.9 \\
\hline Total yearly CF days $^{2}$ & 235 & 150 & 300 & 50.4 \\
\hline Future CF days $^{3}$ & 151 & 10 & 200 & 4.4 \\
\hline
\end{tabular}

${ }^{1}$ The number of total yearly commercial fishing days on the AR site

${ }^{2}$ The number of total yearly commercial fishing days

${ }^{3}$ Future commercial fishing days on the ARs site after deployment

Min: Minimum, Max: Maximum, SD: Standart Deviation 
Moreover, there was a significant increase $(31 \%)$ in the total number of commercial fishing days with the deployment of ARs were determined. $80 \%$ of the CF also indicated that they use the ARs site for other recreational purposes like diving and trips of which recreational trip activities came to be the first place with the percentage of 75 .

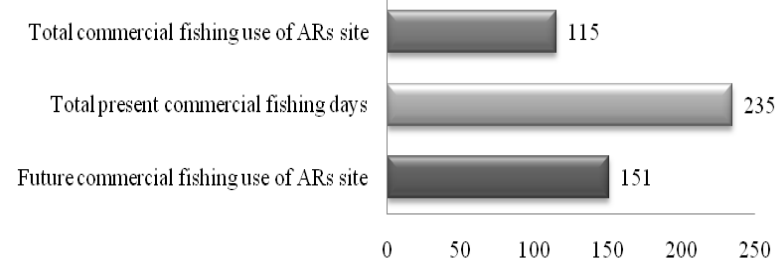

Figure 3. Present and future mean number of commercial fishing use in the ARs site.

\section{Recreational fishing use}

$69 \%$ of the RF queried stated that they use the ARs site during their boat-based recreational fishing activities. Mean number of recreational fishing days by RF in the ARs site were determined as 34; however, this number were determined as 89 days after ARs deployment with the increase of $158 \%$. Then, in the existence of 400 boat-based and shore-based RF, present and future demand of the ARs site were determined as 13,600 and 35,600 recreational fishing days, respectively. In addition, total yearly recreational fishing days were also determined as 124 (Table 4; Figure 4).

Table 4.Descriptive statistics of total yearly recreational fishing days, total yearly present and stated future recreational fishing days in the ARs site

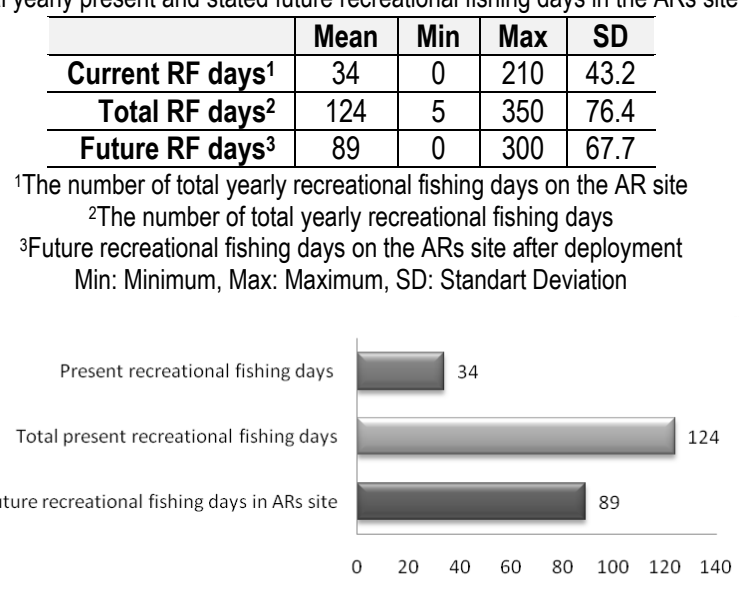

Figure 4. Present and future mean number of recreational fishing use in the ARs site.

It was found that $69 \%$ of the RF uses the proposed ARs site for other purposes including recreational diving and boat trips. Among these different types of uses, recreational diving and recreational boat trips and both recreational diving and boat trips got $44 \%, 28 \%$, and $28 \%$ shares, respectively.

\section{Local residents' use}

Results of the household survey through Altinoluk residents showed that the ARs site in question is used by LR for especially, boat trips $(63 \%)$, recreational fishing $(14 \%)$ and recreational diving $(9 \%)$. Total yearly mean number of recreational uses by LR including fishing, diving and boat trips was determined as 44 days. In addition, $75 \%$ of the LR have increased willingness to participate to a recreational activity in the ARs site after deployment compared to the present situation (52\%) (Table 5).

Table 5. Recreational fishing and diving days of $L R$ after deployment

\begin{tabular}{c|c|c|c|c}
\hline & Mean & Min & Max & SD \\
\hline Recreational fishing & 19 & 0 & 90 & 16.8 \\
\hline Recreational diving & 5 & 0 & 90 & 14.5 \\
\hline \multicolumn{7}{l}{ Min: Minimum, Max: Maximum, SD: Standart Deviation }
\end{tabular}

\section{Conclusion and Discussion}

The respondents interviewed agree that ARs are useful materials that contribute to marine life positively. Based on the individual perception questions regarding the effects of ARs on user groups, it was determined that ARs contribute to the number of user groups and increase their activities, including diving, boat-based recreational fishing and other AR related recreational activities, by stating increased number of recreational activities which supports the hypothesis that ARs generate demand in local economy. There is also an optimistic perception on effects of ARs by local related groups. Apparently, the presence of ARs creates a significant increase in the number of future trips compared to past trips which is also contributing as an economic activity on a micro level.

The only local diving charter in Altınoluk which is only active in summer seasons may also become an important source of recreational demand. Additionally, with the deployment of ARs, there can be an increase in the diving demand, especially, targeting ARs which may also result in the establishment of new diving charters and increased economic activity.

In addition to the recreational activities, ARs are determined as an important tool to enhance commercial fishing demand. Therefore, increased willingness to participate a commercial fishing day was perceived as an increased commercial harvest by the CF. The future studies on increase in catch per unit effort of the $\mathrm{CF}$ can be calculated to put forward the actual commercial effect of ARs.

In conclusion, $158 \%$ increase in recreational fishing days and $31 \%$ increase in commercial fishing days in the ARs site are significant findings to find out the demand in the ARs site. To better analyze the social, economic and biological effects and effectiveness of deployed ARs, it is essential generate constant monitoring frameworks under management plans. 


\section{Acknowledgements}

The authors thank the head of Altinoluk Fishery Cooperative, Halil Ataç, who provided logistical support for the field work and Caner Acar, Fikret Öndes, Huriye Göncüoğlu and Denizcan Durgun for technical assistance during the face to face interviews with respondents.

\section{REFERENCES}

Bell, F.W., Bonn, M.A., Leeworthy, V.R., 1998.Economic Impact and Importance of Artificial Reefs in Northwest Florida.Office of Fisheries Management and Assistance Service, Florida Department of Environmental Administration, Tallahassee, FL. 476 p.

Brock, R.E., 1994.Beyond Fisheries Enhancement: Artificial Reefs and Ecotourism.Bulletin of Marine Sciences 55(2-3): 1181-1188.

Ditton, R.B.,Thailing, C.E. Riechers, R., Osburn, H., 2002. The Economic impacts of sport divers using Artificial Reefs in Texas Offshore Waters In: 53rdthe Gulf and Caribbean Fisheries Institute Annual Meeting, ProceedingsBook,pp. 344-356.

Johns, G., Leeworthy, V.R., Bell, F.W.,Bonn, M.A., 2001.Socioeconomic Study of Reefs in Southeast Florida. Report prepared for Miami-Dade County,Hazen and Sawyer P.C., Miami, FL, 348 p.

GFCM, 2012. Scientific Advisory Committee (SAC), Report of the 12th Session of the Sub-Committee on Marine Environment and Ecosystems (SCMEE),FAO HQs, Rome, Italy, 23-26 January 2012, 23 p.

Lök, A., 2012. Artificial reef applications in Turkey. In: GFCM Scientific Advisory Committee (SAC) 12th Session of the Sub-Committee on Marine Environment and Ecosystems (SCMEE)Report, FAO HQs Rome, Italy, 23-26 January 2012, p. 19

Milon, J.W., 1989a.Artificial Marine Habitat Characteristics and Participation Behavior by Sport Anglers and Divers. Bulletin of Marine Science, 44 (2) 853-862.

Milon, J.W., 1989b.Contingent Valuation Experiments for Strategic Behavior. Journal of Environmental Economics and Management, 17: 293-308. doi: 10.1016/0095-0696(89)90022-3

Miran, B., 2003. Basic Statistics.Ege University Press, ISBN 975-9308800, Bornova, İzmir, 297 p.
The authors would also like to thank the collaboration of the entities involved in answering the questionnaire. This paper is a part of the master thesis called "Assessing the Socio-Economic Effects of Artificial Reef Deployments in The Northern Aegean Sea: Altınoluk Case".

Morgana, O.A., Massey, D.M., Huth, W.L., Hall, R., 2009. Demand for Diving on Large Ship Artificial Reefs. Marine Resource Economics, 24: 43-59.

Oh, C., Ditton, R.B., Stoll, J.R., 2008. The Economic Value of Scuba-Diving Use of Natural and Artificial Reef Habitats. Society \& Natural Resources, 21: 455-468. doi: 10.1080/08941920701681953

Pendleton, L.H., 2004. Creating Underwater Value: The Economic Value of Artificial Reefs for Recreational Diving.<http://californiashipstoreefsinc.onefireplace.com/Resources/Docu ments/Studies/Creating\%20Underwater\%20ValuePendleton.pdf $>(06.01 .2014)$

Schug, D.M., 1982.Political and Economic Aspects of Artificial Reefs in Pinellas County, Florida. Thesis submitted to the Department of Marine Science, University of South Florida, Tampa, FL, 124 p.

Seaman, Jr., W., Sprague, L.M., 1991.Artificial habitats for marine and freshwater fisheries.Academic Press, 285p.

Tunca, S., 2011.Assessing Socio-Economic Effects of Artificial Reef Deployments in the Northern Aegean Sea: Altinoluk Case.Master of Science Thesis, Ege University Graduate School of Natural and Applied Sciences, Department of Agricultural Economics, $172 \mathrm{p}$.

Tunca, S., Miran, B., Ünal, V., 2012. Decisions of Stakeholders for the Proposed Artificial Reef Deployment: Analytic Hierarchy Process Approach. Ege Journal of Fisheries and Aquatic Science, 29(1): 21-29. doi: 10.12714/egejfas.2012.29.1.04

Ünal, V., Göncüoğlu, H., Yercan, M., 2009.Fishery Cooperatives along the Aegean Sea Coast (in Turkish with English summary). SÜRKOOPCentral Union of Fishery Cooperative Associations. No: 1, ISBN: 978605-60880-0-1, Ankara, $131 \mathrm{p}$ 